\title{
食品における応用
}

寺田喜巳男・河 野 博 繁 旭電化工業株式会社（東京都中央区日本橋室町 2-8)

\section{Application of Surfactants in Foods}

\author{
Kimio Terada and Hiroshige Kōno
}

Asahi Electro-Chemical Co., Ltd.

(8, Muromachi-2-chome, Nihonbashi, Chuo-ku, Tokyo)

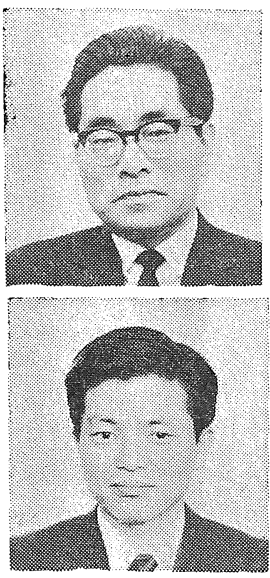

\section{1 は じめに}

わが国における各種産業の急速な近代化の中にあって 食品工業もまた例外でなく，わけても加工食品の多様化 は実に眼をみはらせるものがある。これらの加工食品の 発達を支えているものとして, 約 300 品目に及ぶ食品添 加物があり，一方では色素や防腐カビ止め剤のように不 適正な使用によって問題となることもあるが，「今日の 加工食品は食品添加物なしでは, まったく考えられな い」といっても過言ではない。

これらの食品添加物の中で, 食品用の界面活性剂（乳 化剂) の果たしている役割む大きく，とくに応用面の研 究開発の進展によって, 近年着実に生産および消費が増 大している。

わが国で食品添加物として許可されている界面活性剤 は 表-1 に示寸 5 種である。これらの消費についての確 実な統計資料はないが，モノグリセリドについては，昭 和 37 年に $1,500 \mathrm{t}$ といわれたものが，昭和 41 年には $2,000 \mathrm{t}$, 昭和 42 年では蒸留もの $1,500 \sim 1,600 \mathrm{t}$, 未蒸 留もの $1,200 \mathrm{t}$, 計約 $3,000 \mathrm{t}$ といわれている。

これら界面活性㶡のおるな作用としては乳化剂として 最も利用度が高いが，このほかに湿潤剂, 浸透剤, 結晶 成長促進, あるいは阻止剂, 起ホウ剂, 軟化剂などとし てまことに多岐にわたっている。いずれも最終製品が食 用としてきわめて主要な商品の性質上から合成品につい ては，わが国をはじめ各国ともその乱用防止の観点より 食品添加物としてその使用に対し法規によって種類を制 約している(表-2)。

一般に食品に要求される性質としては, 次のようなも のがあげられる。

1）無害無毒で食品衛生法にかならこと。

2）無味無臭無色で製品の官能面をおかさぬこと。

3）化学变化や微生物的変化を受けにくいこと。
4）界面活性能が強く，また安定性のよいもの。

5）温度や $\mathrm{pH}$ による性能面の変動が少ないこと。

6) ほかの界面活性剤や安定剤をたは食品成分と相乗 的に働くこと。

7) 使用に便利なこと。

8）製品の収量を低下しないこと。

9）コストが低廉であり，また市場性があること。

表-1 日本の場合

\begin{tabular}{|c|c|}
\hline 界 面 活 性 荗 & 用 \\
\hline $\begin{array}{l}\text { グリセリン脂肪酸エステル } \\
\text { 脂肪酸プロピレングリニールエステル } \\
\text { ショ糖脂肪酸エステル } \\
\text { ソルビタン脂肪酸エステル } \\
\text { 大豆リン脂質 }\end{array}$ & 乳 化 剂 \\
\hline $\begin{array}{l}\text { アルギン酸ナトリウム } \\
\text { アルギン酸プロピレングリコールエステル } \\
\text { 繊維素グリコール酸ナトリウム } \\
\text { メチルセルロース } \\
\text { その他 }\end{array}$ & $\exists$ \\
\hline
\end{tabular}

つぎに界面活性剂が各種の食品工業に利用される作業 機構につきそれぞれ示例をもって記載していくことにす る。

\section{2 乳化剂としての利用}

油脂を主体とするマーガリン，マヨネーズ，ピーナツ バターなど脂肪性の乳化食品はむろんのこと，その製造 が乳化工程を経て製造される食品には乳化剂の使用はき わめて効果的であり，製品に及ぼす影響も大きい。マー ガリン工業にあっては 1933 年 $\mathrm{Hsrris}^{1}$ が乳化剂とし てモノ、ジグリセリドの使用を提案してから今日に及ん でいる。その後も Schoenfield ${ }^{2)}$ などのように $\mathrm{OH}$ 基を 多く導入した強力な乳化剂なども考案されているが, 最 近のマーガリン製造装置はボテーターなどの出現によっ 
表-2 米 国 の 場 合（1968 年 9 月現在）

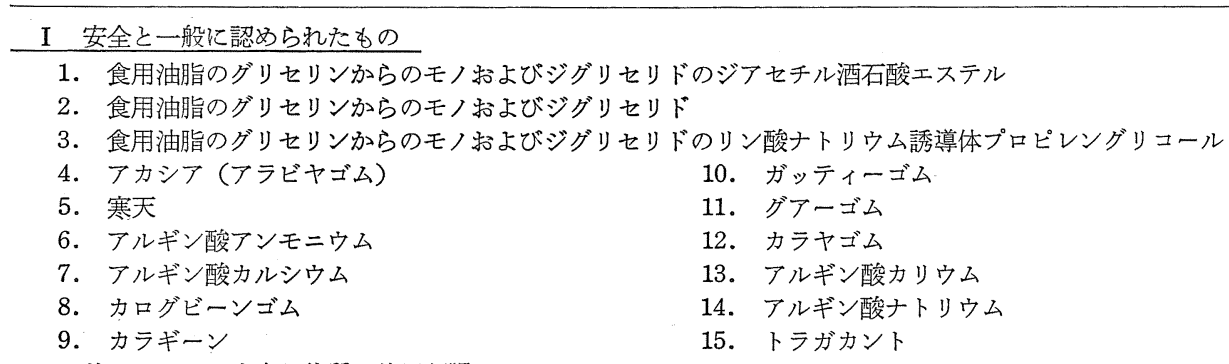

III使用のための安全な物質, 使用制限のあるもの

1. コール酸, デスオキシコール酸, グリココール酸, 牡牛胆汁抽出物，タウロコール酸（またはそのナトリウム塩） ·乾燥卵白中 (0.1\% 以下)

III 規則によって許可されたもの

1. アラビノガラクタン……...着香ベース中の乳化执よび安定剤，基準のないドレッシング，プディング用

2. ステアリン酸カルシウム-2-ラクチレート

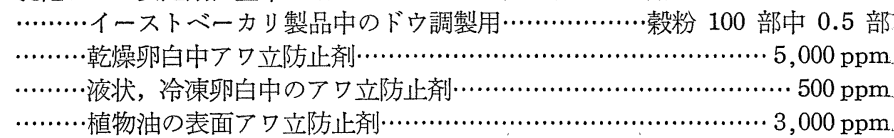

3. カラギーン (および塩) 乳化剤，安定剂，濃化剤，このような使用が認められない規格食品は除く……

4. 脂肪酸, 乳酸エステル......

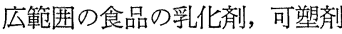

5. 脂肪酸のグリセリン乳酸エステル…食品中の乳化剂, 可塑剤……

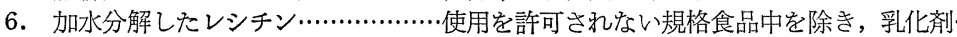

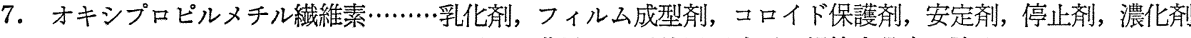
ただし，菓子および使用不許可の規格食品中は除く

8. ポリオキシェチレン（20）ソルビタントリステアレート

………ケーキ中の乳化剤, 単独で $3,200 \mathrm{ppm}$ ケーキ中の乳化浏 4,600 ppm のポリソルベート 60 とともに $\cdots \cdots \cdots 3,200 \mathrm{ppm}$ (合計 $4,600 \mathrm{ppm}$ ) 植物油の表面を弾力性をもたせるための乳化剤, 単独で………4, $4,000 \mathrm{ppm}$ またはソルビタンモノステアレートとともに，または ポリソルベート 60 および牛乳またはクリーム製品中 冷凍デザート中の乳化剤，単独でまたはポリソルベート 60 とともに

9. ポリオキシエチレン（20) ソルビタンモ)オレート（ポリソルベート 80) $1,000 \mathrm{ppm}$

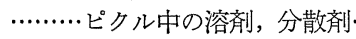
$500 \mathrm{ppm}$

………薬味入りグリンピースカン詰中のジル（せりに似た植物） 油中の溶剂，分散剂…... $30 \mathrm{ppm}$

……..乳化剂, 冷凍デザート中, 単独でまたはポリオキシェチレ

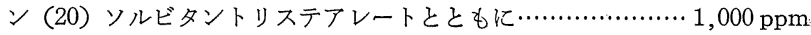
乳化㨈非基準化食品用のショートニング中…….................

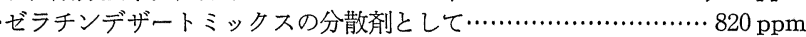

………家畜の脱羽用沸騰水の湿潤剂...... $175 \mathrm{ppm}$ 1 日のビタミン投薬量中 $300 \mathrm{mg}$ 1 投薬量が 30,000 I.U.より含量の多いビタミンA $500 \mathrm{mg}$ ………イースト消ホウ用 $40,000 \mathrm{ppm}$ イースト中 ... $4 \mathrm{ppm}$ 食塩製品の表面剤 $10 \mathrm{ppm}$ 食用油の乳化剂として特に指定された食ジ療法用食品中 ………1日の摂取量として $360 \mathrm{mg}$ を越えぬとと

10. ポリオキシエチレン（20）ソルビタンモノステアレート（ポリソルベート 60)

·䄻化剂, 植物油の表面を弾力性をもたせるためのもの, 単独 でまたはンルビタンモノステアレートとともにまたはポリオ キシエチレン (20) ソルビタントリステアレートとともに $\cdots \cdots, 4,000 \mathrm{ppm}$ .乳化剂，ケーキおよびケーキミックス，単独で………………4, $4000 \mathrm{ppm}$ 乳化剂, ケーキおよびケーキミックス中ソルビタンモノステ

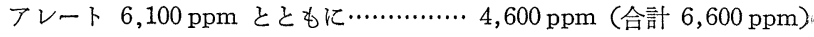
..乳化㓮，ケーキおよびケーキミックス中ポリオキシェチレン

(20) ソルビタントリステアレート $3,200 \mathrm{ppm}$ とともに …... 4,600 ppm (総計 $4,600 \mathrm{ppm}$ ) 


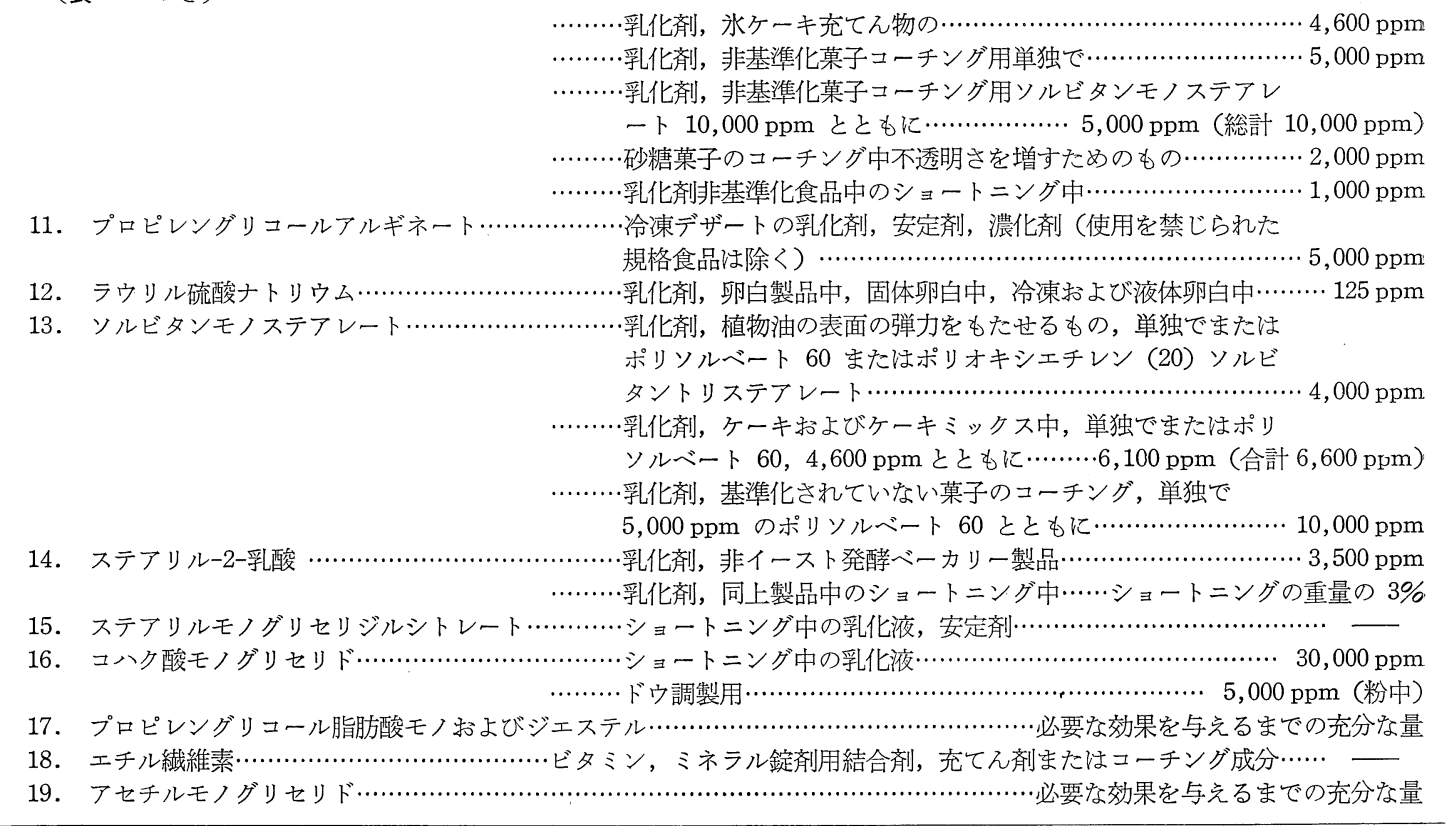

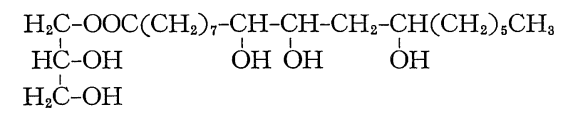

て製造時における乳化工程に際して必ずしも乳化剂を必 要とはしなくなっている。しかしながら，モノグリセリ ドが貯蔵中の水滴分離を防止すべき乳化剂として $0.2 \%$ 程度が使用されており,さらにマーガリンを調理用に使 用する場合の水は水防止，あるいはアワ立ち防止剤とし てレシチンが 0.1 0.3\% 程度用いられている。水はね 防止剂としては Harris ${ }^{3)}$ などの推賞するモノステアリ ンスルホアセテートなどもあるが

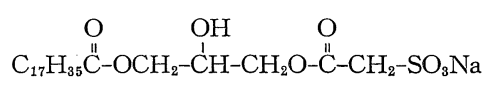

レシチンで充分に目的を果たしている。マーガリンの 場合, 水は䄈止の観点からは乳化は細かいことが望ま れるが，一方あまりに細か過ぎる際には食味感覚にも影 響し，適当ではないのでおのずとその限界があり，乳化 剂の使用に当たって考慮が望ましい。Sambuc ${ }^{4)}$ はマー

表-3 マーガリンの乳化と性状

\begin{tabular}{|c|c|c|}
\hline $\begin{array}{c}\text { 分散水相球の径 } \\
(\mu)\end{array}$ & $\begin{array}{c}\text { 含有量 } \\
(\%)\end{array}$ & マーガリンの性質 \\
\hline $\begin{array}{l}<1 \\
>3\end{array}$ & $\begin{array}{c}80 \sim 85 \\
\text { なし }\end{array}$ & $\begin{array}{l}\text { 重い脂肪味濃厚,グリージーな食味 } \\
\text { 微生物の繁殖防止 }\end{array}$ \\
\hline $\begin{array}{r}1 \sim 5 \\
5 \sim 10 \\
10 \sim 20\end{array}$ & $\begin{array}{r}95 \\
4 \\
1\end{array}$ & 軽い食感を得る \\
\hline $30 \sim 40$ & $\begin{array}{l}1 \% \text { 以 } \\
\text { 上含有 }\end{array}$ & $\begin{array}{l}\text { 風味改良, 保存性減少, 分離の危 } \\
\text { 険, 恧微生物性危䧍 }\end{array}$ \\
\hline
\end{tabular}

ガリン中の水滴の分散に関して調べ，水滴が大きく充分 に分散していないと微生物が繁殖しやすくなると報告し ている。

表-3 はマーガリンの乳化と品質の関連を示す。

マーガリンは分散水相の大きさによってのみならず， 乳化の型を界面活性剤の利用と工程の考察により変型す ることによってレオロジ一的性質，食感などを改良する ことも可能で従来のマーガリンの W/O 型マーガリンと はまったく逆の $\mathrm{O} / \mathrm{W}$ 型乳化可塑性油脂), あるいは二 重乳化型マーガリン6)( $\mathrm{O} / \mathrm{W} / \mathrm{O}$ 型) などを製造し得, そ れぞれ乳化可塑性油脂の特徵を適用した用途が開発され ている。

Brown ${ }^{7)}$ はピーナツバターにモノグリセリドを安定剤 として使用し，かたい感じ (stickness) を減少させダ液 との混合を容易にする効果があると解説している。

ショートニングにも多くの乳化剤が混合使用されてい るが8)，この場合はショートニングを製造するための条 件ではなくして，ショートニングを使用してケーキなり パンへの使用上の効果を考えて配合されているものであ るから，それぞれ利用工業での機構を合わせて論ずる方 が妥当であるら。パウンドケーキ，レヤーケーキなどの ように油脂を生地中に配合するケーキの場合はショート ニングの製造時, 生地混合工程中に油脂に抱き込まれる 気ホウ，すなわちクリーミング性と乳化剂によって焼成 ケーキの巣立ち, 容積に大きい影響を及ぼすむので, そ の状態は 図-1 によって理解することができる。

したがって, 乳化剂の効果はきわめて顕著に現われる 


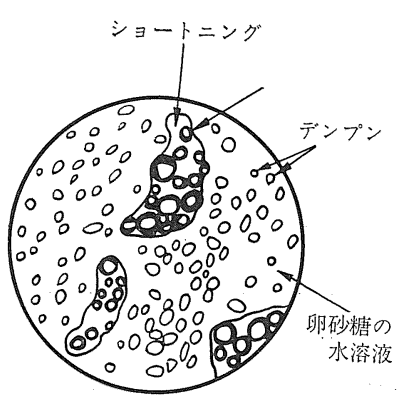

図-1 ケーキ生地中の乳化状況

表-4 モノグリセリド入りショートニングのケーキ焼成試験

\begin{tabular}{|c|c|c|}
\hline & 普通ショートニング & $\begin{array}{l}\text { モノグリセリド } 6 \% \\
\text { 添加ショートニン゙ }\end{array}$ \\
\hline 生 地 比重 & 0.888 & 0.885 \\
\hline 生 地 状 態 & $\begin{array}{l}\text { カードリングを起こ } \\
\text { す }\end{array}$ & $\begin{array}{l}\text { きかめて軟かく滑ら } \\
\text { かである }\end{array}$ \\
\hline ケーキ外観 & やや均質性に欠く & 均せいのとれた型 \\
\hline 焼き上りの目方 & $157.5 \mathrm{~g}$ & $168.8 \mathrm{~g}$ \\
\hline 容 積 & $345 \mathrm{~m} l$ & $430 \mathrm{~m} l$ \\
\hline 食 & $\begin{array}{l}\text { ねっっとりして口中で } \\
\text { だんご状 }\end{array}$ & $\begin{array}{l}\text { 味, 口当たりよく軽 } \\
\text { くできている }\end{array}$ \\
\hline 内 & 貝がつえで巣立ち不 & 色調白く宩立ち良好 \\
\hline
\end{tabular}

もので，モノグリセリドを添加したショートニングの効 果はパウンドケーキに用いた場合 表-4より明りょうで 㐫る。

近年, ケーキの連続製造方式, あるいは迅速製造の要 望から従来の可塑性型のショートニングでなくて液状ま たは流動状のショートニングがクローズアップされてき たが，このような状態になるとショートニングにクリー ミング性を頼れす，抱気剤として界面活性剤の利用が考 えられ，数件の特許 ${ }^{9}$ が出願されているがいずれも一長 一短がある。ケーキへの乳化剤としてモノグリセリドを ショートニングに添加する場合の種類, 添加量などは, $\mathrm{Mack}^{10)}$ などにより詳述されている。Kuhrt ${ }^{11)}$ はケ一キ の容積については不飽和脂肪酸をもった油脂からのモノ

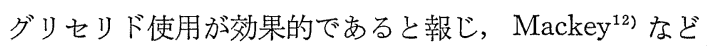
はバターとの併用によるケーキへの効用を記載してい る。Pratt ${ }^{13)}$ らは油脂を配合するケーキにはケーキ全量 に対してモノグリセリド $0.7 \%$ あるいはンルビタンモノ ステアレートまたはモノパルミテートを $0.28 \%$ とポリ オキシエチレンソルビタンモノステアレートあるいはパ ルミテート $0.07 \%$ との混合物の使用を推め, ケーキの 巣立ち, 均一性, 容積を増大し, 柔軟性の改良に効果的 であるとしている。Young ${ }^{14)}$ などの乳化剤は $\beta$-プロピ オラクトンと脂肪酸あるいは脂肪族アルコールとの反応 物でこれを $20 \%$ 以下ショートニングに添加することに よりケーキの柔軟度と容積の増大を計っている。

キャラメルにも乳化剂の効用が認められ ${ }^{15)}$, 歯でかむ
際のチューイング性を改良し，製品の切断などの作業， 機械性が改良される。乳化を細かくすることは夏期にお

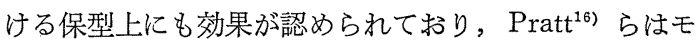
ノグリセリド $0.5 \%$ あるいはソルビタンモノステアレー ト $0.4 \%$ とポリオキシエチレンソルビタンモノステアレ ート $0.1 \%$ の組合せを推茂している。

またキャンデー類はキャラメルより惹つめ温度が高い ものが多く $\left(130 \sim 150^{\circ} \mathrm{C}\right)$, とくに油脂を含むものにつ いてはモノグリセリド，ソルビタンエステルのみでは添 加油脂の分散が困難であったが, ショ糖エステル (HLB7〜13) を添加することにより著しく改善されるという。 またキャンデー類のショートネスを増加し, 新しいタイ

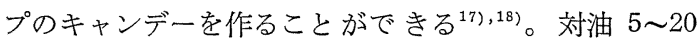
\%, 製品当たり $0.4 〜 1.5 \%$ 程度で乳化脂を作るか，ま たは油脂を使用しないキャンデーでは濃厚溶液としてお いて, 冷却工程直前に加え, 充分混合するのがよい。

このほかにも油脂を乳化する食品には，ほとんど乳化 剤が使用されている。天然の界面活性剤を有する物質は その配合時において重要な役割を演し，マヨネーズの製 造の際におけるカラシ，卵黄のごとくである。卵白の乳 化力は卵黄のわずか $1 / 4$ 程度 $^{19)}$ で, Robinson ${ }^{20)}$ は冷凍 卵黄は安定な乳化物を作るのに効果があるが, 輸送の場 合に不安定になることを報じている。乾燥卵黄もよい乳 化剂として使用でき, 最初 $\mathrm{pH} 8.6$ 程度のアルカリ性の 水中に分散させるととくにその効果が大きいとの報告 ${ }^{21)}$ もあり，Epstein ${ }^{22}$ はグリセリン，酢酸を含有するサラ ダクリームに適した特殊な卵黄を調製している。

卵黄の界面活性物質はおもにレシチンとコレステリン であり,レシチンは $\mathrm{O} / \mathrm{W}$ 型に, コレステリンは $\mathrm{W} / \mathrm{O}$ 型エマルションに好適な乳化剂である。Corran ${ }^{23)}$ は 50/50 の O/W 型エマルションが W/O 型に反転するの はレシチン/コレステリンが 8: 1 以下になったときで あると報じている。さらにマヨネーズの乳化および安定 化には, カラシ粉の添加効果も重要であり, カラシ粉は 微粉末のものの方が乳化力が強く粗粉末では充分な効果 が出ないといわれている ${ }^{24)}($ 表-5）。

乳濁したジュースの製造に米国の例としてポリオキシ エチレン脂肪酸エステルのような界面活性剂がエッセン スフレーバーの乳化分散剤に利用され, 乳化の光学的性 質をたくみに利用している。乳化香料の作成については

表-5 カラシ粉の乳化力

\begin{tabular}{clll}
\hline 微粉末カラシ粉 & $0.17 \%$ 以下 & W/O 型 \\
$" \prime$ & $0.7 \%$ & W/O 型になりやすいが不安定 \\
$" \prime$ & $1.25 \%$ & 型が不定で不安定 \\
" & $1.7 \%$ & $\mathrm{O} / \mathrm{W}$ 型になりやすいが不安定 \\
" & $2.1 \%$ 以上 & $\mathrm{O} / \mathrm{W}$ 型 \\
粗粉末カラシ粉 & $1.7 \%$ 以下 & W/O 型 \\
" & $5.9 \%$ & 型が不定で不安定 \\
\hline
\end{tabular}


Saul ${ }^{25)}$ らが報告している。乳化型であっても必要あれ ば透明性のフレーバーエマルションも作成可能で WhitImore, Linehan ${ }^{26)}$ らは食用フレーバーとして数種の芳 香精油エマルションの透明性を検討している。そのほか オレンジ油, レモン油, グレープ油の乳化には, ショ糖 モノパルミテート，ステアレートなどのショ糖エステル 功他の乳化剤に比較してすぐ机て抢り ${ }^{27)}$ ，ジュースクラ

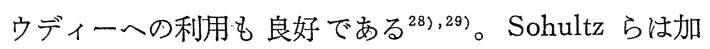
熱溶解させた糖類に精油を添加し, 固化後粉末化する粉 末香料の製造法に扔いて，製造中および製品保存中の香 “料の保留にショ糖ジパルミテート ${ }^{30)}$ ，レシチン ${ }^{31)} 0.1$ 〜5\% 添加が有効であること。また乳化香料を経て糖類 中に精油を含有させる粉末香料の場合には, ショ糖モノ パルミテートが有効なこと ${ }^{32}$ を報告している。

天然精油の可溶化には界面活性剂の HLB 価が少なく とも 10 以上であることが必要であり高いほどよい。シ ヨ糖エステルでは HLB 価不足ぎみであり, ポリオキシ エチレンソルビタンエステル系のものがよい(33)といわれ 一ていが，一般にフレーバーやエッセンスは油の溶解性 を高める関係から 70〜85\% のアルコールを含有してい る。このような濃度でも透明性を得るためにはかくはん したり，口過しなければならず香料の一部はロスする, そこである程度の親水性をもった乳化剂を使用して，フ レーバーやエッセンスを透明型あるいは乳濁型のエマル ションを調整して使用しなければならない。水に入れて も透明性を得るためには香料精油の数倍の乳化剂を用い ネ机ばよく, 乳濁分散型では乳化剂使用量は少なくてすむ。

しかし, 乳化剂の作用やアルコールによる可溶化は補 助的な手段でむあるため,アルコールの低濃度と乳化剤 の適量組合せによるバランス調整がよく使われる。この ような場合は乳化剈の使用によってかくはんや口過工程 が除去できる。フレーバー分散を可溶化透明型と乳濁乳 化型とに分け秃ば, 前者はコーラ,クリームソーダなど であり., 乳濁型はオレンジジュースが該当する。

サーズの乳化関倸についてはFaivre ${ }^{34)}$ の研究があり, 记くにソフトチーズ (Camembert, Bric, Belphase な ど）の製造に当たって，ミルクに対し $0.05 \sim 1.0 \%$ に当 たるショ糖エステルまたはショ糖エステルモノグリセリ

ド混合物を $0.1 \sim 5 \%$ の水溶液として加えることによ り，ミルクからの沈殿量が多くなり。ソフトチーズの安 定性が向上し, フレーバーの増強が促進されるという。 カードがよりむらなくでき,カード中のアワの混入が減 り乳ショウへのカード混入が防げチーズの収量が増加す るといわれている゙5)。

インスタントカレー, カレールウは油脂を大量に含有 して抒り，油の乳化分散が良好かつ安定で食味のよい製 品とするためには，ショ糖エステル，モノグリセリド， ソルビタンエステルなどが乳化剂として不可欠であり，
ほとんどのカレー製品に用いられている。添加量は対油 1 3\% 程度である ${ }^{36), 37) 。 ~}$

調味料のうち, 含油しょう油や含油ソース ${ }^{38), 399}$, 含 油粉末調味料 ${ }^{40)}$ ，ドレッシング，マヨネーズ用粉末食 酢 ${ }^{41}$ などの乳化剂として, 各種の食用界面活性剂が単用 または併用で使用される。このほかに親水性のショ糖エ ステルを微少量添加したしょう油は表面に黒色などの浮 上物を生じにくくなり，また甘草エキスやかび止め剤が 原因となって起こるしょう油の浮遊物防止にもショ糖エ ステルが有効であるといわれる ${ }^{42,43)}$ 。またソース類の 沈殿防止にもショ糖エステルの使用が有効であり ${ }^{44)}$ ，実 際に使用している。

また，かまぼこ，ちくわ，魚肉ソーセージなど水産練 り製品への界面活性剤の利用効果は,

1）副原料として用いられるデンプンの老化を防止 し, デンプンの腰を強くする(ジェリー強度の増 加)。

2）包装かまぼこなどのフィルムはく離性を向上させ る。

3）カッ変を防止する。

4）焼ちくわの棒ぬきが簡単になる。

5）焼きもののこげつきを緩和する。

6) 魚肉ソーセージの油分の乳化分散を向上し, 官能 的にすぐれた製品となる。

などである ${ }^{45}$ 。モノグリセリド，ショ糖エステル，ソル ビタンエステルを擂潰時に水分散液として $0.1 \sim 1 \%$ 加 えて用いるが，添加方法がわずらわしいため，モノグリ セリドの水分散性改良品, モノグリセリドと油脂配合 品, モノグリセリドとショ糖エステルのペースト状配合 品などが使用されている。ショ糖エステルは包装かまぼ このはく離剤として特に有効であり，すり身当たり 0.1 \%を水溶液として添加するとよい。しかしながら，水産 練り製品は比較的地方色が大きな商品で, 処方も多様で あり，乳化剂はどの製品にも一様に有効といらわけには いかないことが多いし，また添加のやりかた(たとえば， 多量に加光過ぎた場合など)によってはかえって逆効果 を示す場合がある。

つぎに肉製品に対しては乳化剤はあまり利用されてい ないが,ソーセージ,プレス八ムなどの保水性を向上し， またレバーペースト，ボローナソーセージ46)のような油 脂含量の多、製品の油の分離防止のため, 乳化剤として 充分有効に使用される可能性がある。ショ糖エステル を, 単独またはポリリン酸塩との併用でピックルまたは 調味液に 0.04 0.3\% 添加して使用すると，八ム，ソー セージ ${ }^{47)}$, 魚, 鯨, 牛肉カン詰为 ${ }^{48}$ の保水性を向上し, 経日変化による食感の低下を防止するのに有効であると いう特許も出願されている ${ }^{499}$ 。

最近話題になっている大豆タンパクなどから製造され 
る人造肉（紡糸タンパク製品）は加工上, 油脂, 調味 料, 香辛料を加える必要があり, これら添加物の均一な 分布を形成させるために各種の乳化剂が利用される

その他，食品用グレース郕としての利用も多く畜肉， 魚肉など鮮度の低下しやすい食品について, 酸化, 水分 の蒸発, 腐敗などを防ぐ目的で, コ料, 油剤などの各種 のグレース剤が発達してきている。かまぼこ, ソーセ

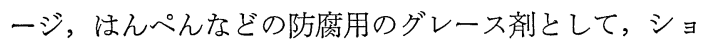
糖エステル，親水性のソルビタンエステルなどの 1 20 \%水中分散液とし，ホモゲナイズしたものが有効である といわれる ${ }^{50)}$ 。また魚類のグレースには酸化防止剂が用 いられるが，BHA，BHT などフェノール系の薬荗は水 に難溶性なため，乳化剂を配合して水中分散性を与えた 製剂 ${ }^{511}$ が用いられている。このほか 2 3 の油性グレー ス剤の水中油型 $(\mathrm{O} / \mathrm{W})$ 乳化剂としても利用されてい

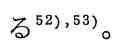

また, 外米, 古米の栄養強化と味覚向上を計る目的で 丹羽ら ${ }^{54)}$ は乳化剤にモノグリセリド，ソルビタンエステ ルなどを用い，カルボキシメチルセルロース (CMC), アルギン酸ナトリウムなどを安定剈として併用し, さら にビタミン類を添加乳化した乳液 $(\mathrm{O} / \mathrm{W}$ 型エマルショ ン）を穀粒に吸着させている。この種のものはすでに市 場にも出ており, 食味, 光沢, 精米での歩留りなどの 向上が認められ，胴割米が少なくなるともいわれてい る。

\section{3 起ホウ剂としての利用}

ケーキの中で油脂を混入しないスポンジケーキ, エン ゼルケーキ（最近は風味改良, 老化防止などの観点より サラダ油などの液状油が添加される傾向にある) などに 界面活性剤を利用することは, 起ホウ剤としての効果を ねららものであり,ケーキ製造の際の混合方法も簡素化 するなどの利点も誘導される。

この種の界面活性剤としては, タンパク系のペプチド 類とモノグリセリドなどのような脂肪酸エステル化物が 主体のものとに分かれる。

前者は, 動植物タンパク質を弱アルカリで分解する方 法55などがあり，また冷凍卵の多くがケーキに使用され るところでは, 生卵は対し起ホウ性の低減を補うために クエン酸とイソプロピルアルコールのモノエステル ${ }^{56)}$ ど微量を添加して起ホウ性の増大を計ったり,トリアセ チン $0.1 \%$ を添加してアワ立て時間の短縮を計ったりす る方法が考案されている57。

一方後者では, Johnston ${ }^{58)}$ がソルビタンモノエステ ルおよびポリオキシソルビタンモノエステルを起ホウ剤 として利用し,ケーキ容積の増大と柔かいケーキを作る のに効果的なことを報しててる。このさい，ケーキの材 料混合手順も界面活性剤の使用に影響寸るもので，モノ
グリセリドを用いてこの間の関係を Harper ${ }^{59)}$ は記載し ている。そのほかケーキへの起ホウ剤としての応用文献 は, Cressey ${ }^{60)}, \mathrm{Coppoch}^{61)}$ ら枚挙にいとまがない。

モノグリセリドの $\alpha$ 型結晶は通常不安定で $\beta$ 型である が，モノグリセリドのベーキング性能，すなわち起ホウ 剤的な役割は $\alpha$ 型の方が好ましい。この点 $\mathrm{Kuhrt}^{62)} ら$ は 16〜20 の炭素数を有する飽和脂肪酸のモノグリセリ ド $30 \sim 60 \mathrm{~mol} \%$ にプロピレングリコール 脂肪酸 エス テル 40〜65 mol \%を混合し，モノグリセリドの結晶 を $\propto$ 型変性体に保つエステル混合物の結晶を結合結晶 (conjoined crystal) と呼び, アワ立ち型のケーキにも 水に対する分散性もきわめて良好で，またこれらの部分 エステル混合物にソルビン酸を添加することによりカビ 止め効果および水への分散を効果的にすることを知見 に，これを含有した結合結晶はスポンジケーキのような アワ立ち型ケーキの容積や巣立ちを著しく改良すると述 ベている。

国内にも昭和 37 年ころからモノグリセリド，ショ糖 エステル，ソルビタンエステル，ソルビットなどを配合 たスポンジケーキ類の起ホウ剤が開発され，今日ではし 約 10 の銘柄 (リスホッピー, ニットー SP, ハイアッ プなど）が年間約 $2,000 \mathrm{t}$ 製造販売されており, 洋菓子 作りにはほとんど不可欠の原料となっている。これら起 ホウ剤については，すでにいくつか報文 ${ }^{63) ~ 67) も あ る か ゙ ， ~}$ その組成は蒸留モノグリセリド $5 \sim 30$ 部, ソルビタンエ ステル 0〜15 部, ショ糖エステル 5〜20 部, レシチン 0〜10 部, ソルビット 30〜40 部, そのほかエチルアル コール，プロピレングリコール，グリセリン，水などか らなり, 親油性の乳化剂を親水性の乳化剂㧍よび可食性 の溶剤によって水中に可溶化し，ソルビットなどにより 安定化したものである。作用効果はケーキバッターの気 一液界面に扔ける表面張力を低下させて, 発ポウを促し。 できたアワの膜面に乳化剤が配列することによって膜面 を強固にし，発ポウ性を増強するためにバッターの安定 度が向上するものと考えられ，ケーキバッター当たり 1.5 2.5\% の使用ででき上りケーキのボリウムが 10 $20 \%$ 向上寸る。

また他方，油脂を使用するケーキの製造にあっても， 近年注目されてきている液状ショートニング (liquid shortening) あるいは流動ショートニング (fluid shor tening) にあっては, 従来の可塑性ショートニング (plastic shortening) に扔けるクリーミング性は期待できず, これに代わって起ホウ剤 (aerating agent) を界面活性 剤に探索することが開発されつつある。この場合ケーキ バッター中に拉ける抱気状況は 図-1 の可塑性ショート ニングのそれとは異なり，水相中に分散した気ホウはそ の回りを微細の乳化分散脂肪球に吸着されているような 型をとっている。 
宅ノグリセリド，シグリセリドの乳化剤は 1930 年こ ろより使われており，クリーミング性を非常に改良して きた。その後も多くの界面活性剤が現われ，

Lactated esters of monoglyceride

Diacetyl tartaric acid esters

Propylene glycol esters of fatty acids

Polyoxyethylene sorbitan esters

Sorbitan esters of fatty acids

などによってクリーミング性は固体脂に依存することは 少なく，固体脂 $20 \sim 30 \%$ に対し 10\% 程度の界面活性 剤で代替でき性能もよいのが開発されている。

一般にこのクリーミング性から進んで，バッター中に 形成されるアワについても大切な問題である。このアワ がケーキのセルとなるので, ケーキの強さ; 張力, 容 積, きめ, 型などはアワのサイズ, 分布, 膨張, 移動, 膜の浸透性，安定性に影響を受ける。

通常, 微細なアワほどその内圧は大きく, アワの数が 少ないほど個々のセルは大きくなり，ケーキのきめはあ らくなる。顕微鏡観察によれば, バッターの放置時閒に つれてしだいに大きくなる。乳化剤を有効に利用してい るものほど，アワの安定性のよいことがわかる。統計的 なデータからは, アワに抱き込まれた空気の量, 大き さ, 分布, アワの数などの最適特性は平均アワの大きさ 約 $45 \mu$, 均一な気亦ウ球, 標準偏差 $<1.7$, 生地 $1 \mathrm{~g}$ 中 の気ホウ数約 $25 \times 10^{6}$, オーバーラン約 $175 \%$ といら結 果 ${ }^{68}$ も出ている。アワは一定の粘度をもつ液体中ではア ワの上昇速度はアワの半径の 2 乗に比例し, 粘度に反比 例することにより，バッターの粘度もクリーミング性と 合わせてケーキ製造上の重要な問題である。

最高のクリーミング性効果を得るには, 各乳化剂系の バランスが必要で多くの場合乳化剤単独では不充分であ る $^{69), 70)}$ 。この場合クリーミング性能のすぐ犰た乳化剂 と補助的な役割を果たすものとに分類できる。

前者に属するものとしては乳酸, クエン酸, 酒石酸, マレイン酸系のオキシ酸のエステル類，モノグリセリ ド，プロピレングリコールなどのエステルがあり，後者 の補助歳として効果のあるものとしてクエン酸とプロピ レングリコールと高度飽和脂肪酸モノグリセリドとの反 応生成物 ${ }^{69)}$ とか， ステアリルモノグリセリドシトレー ト ${ }^{70)}$ な゙゙がある。この内近年特に開発のめざましい乳酸 エステルは, 乳酸の反応基として $\mathrm{OH}, \mathrm{COOH}$ 基を 持っているので, 脂肪酸, グリセリン, 乳酸の $\mathrm{mol}$ 比, 反応条件によって反応生成物はきわめて複雑多種で ある ${ }^{71)}$

$\mathrm{Fett}^{72)}$ は乳酸エステルをカラムクロマトグラフィーで 4 区分に分け，それぞれのホワイトケーキ試験の結果, グリセリンに 1 個の脂肪酸と 2 個の乳酸が付加し, 2 個 の遊離の $\mathrm{OH}$ 基をもつものがよく， かつその $\mathrm{OH}$ 基
がグリセリンにより乳酸であるものの方が効果的である と報告している。

以上の液状ないし流動ショートニングはベースの油を 100\%とした界面活性剤の組合せであるが，水を混合し 水中油型に乳化することによって生地への分散性を向上 し，かつ起ホウ性を付与したものもすでに市場に出回っ ている ${ }^{73)}$ 。このような $\mathrm{O} / \mathrm{W}$ 型起ホウ性乳化油脂も一般 のショートニング類と同様，その起ホウ性はレオロジー 特性に由来している。一般に油脂のクリーミング性によ る生地の比容積（比重の逆数）とケーキ容積の関係はつ ぎの 図-2 のように直線的な比例関係がある。

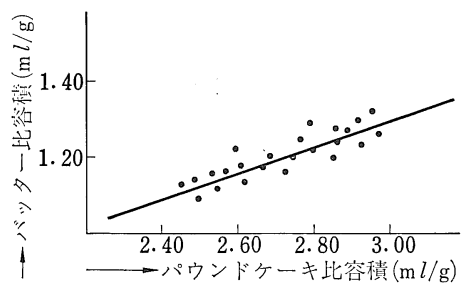

図-2 生地とケーキ容積の関倸

ここで大切なことは，油脂のクリーミング性が温度に よって著しい影響を受けることである。油脂は温度によ りレオロジー特性が変わり, 起ホウ性はこのレオロジー 特性に負うところが大であるから，使用される油脂は広 範囲の温度にわたって良好なクリーミング性を持続する ことが望ましい。このことは温度による影響として使用 されるショートニングの温度来歴もクリーミング性に重 要な影響を及ぼす。したがって使用前マーガリン，ショ 一トニングの保管温度に留意することが大切である。こ の点, $\mathrm{O} / \mathrm{W}$ 型の油脂はごく少量の水で細かい油粒子を おおった形態のものであるから，外相の水が凍結しない 限りレオロジー特性は変わらずクリーミング性も温度に よる影響をまったく受けず，またケーキバッターと同じ 乳化型であるため，バッター中への分散性にすぐれきわ めて短時間でホイップし，安定性もケーキボリウムも好 ましい評価を得ている。

また Geisler ${ }^{74}$ はモノグリセリド,ソルビタンステア レート，ポリオキシェチレンソルビタンモノステアレー トの組合せによって乳化起ホウ性流動油脂を調べて，動 物性油脂は植物性油脂に比べ流動性を失いやすいこと， ソルビタンモノステアレートは製品の粘度を増し，ポリ オキシェチレンソルビタンモノステアレートは流動性を 向上させる作用のあることを示している。製造法は界面 活性剤を油相に溶解して油脂とほぼ同量の水とを別々に $55^{\circ} \mathrm{C}$ に加熱しておき，油脂中に水をかくはんしながら 加え，ホモジナイザー $\left(2,000 〜 2,500 \mathrm{lb} / \mathrm{in}^{2}\right)$ を通じて 乳化させたものである。安定性は油脂の性質, ソルビタ ンモノステアレート/ポリオキシエチレンソルビタンモ 
ノステアレートの比率および量, モノグリセリドの性質 と量の 3 要因に影響され, ソルビタンモノステアレー ト/ポリオキシエチレンソルビタンモノステアレートが 1.5 以下，30/70 が最適で合計 $3.5 \%$ を加え，モノグリ セリドは 5〜6\% を加えるのがベーカリ一用には好適で あるとしている。

アイスクリームに界面活性剤を利用することは, 乳化 および起ホウ的な作用によって製品を乾いた状態にする 効用が認められている。 $\mathrm{Jracy}^{75)}$ はポリオキシエチレン ステアレート，モノグリセリドなどを用いてアイスクリ 一ムへの影響を調ベ，ポリオキシエチレンステアレート $0.03 \%$ 添加によってホイッピングする時間を $1 / 3$ に減 少し組織の改良されることが認められている。Arbuck$1 \mathrm{e}^{76)}$ は界面活性剤の水の結晶, 空気アワの大きさ, 組織 への影響を観察し，過剰乳化はかえってロどけを悪化 し，アイスクリームがママコのある溶け方をしてよくな いと報告している。

アイスクリームには現在, モノグリセリドがもっとも 多く利用されているが，不飽和酸モノグリセリドは乾燥 性, 抱気速度, 低いオーバーラン, 重い感じのボデーを 助長し, 飽和酸モノグリセリドは逆に抱気性は遅いがオ ーバーランが高く，抱気性の軽いボデーを作る傾向がう かがえる。なお，アイスクリームの乳化と乾燥性につい ての理論的解明は近年 Keeney ${ }^{77)}$ らによって提案されて いる。ホイップドクリームの製造に際しても界面活性剤 がアワ立ち促進的作用として利用される。この場合には ホイップの初期段階にてアワ立ちを加速し，かつ腰のあ る状態に適当にホイップさせるような界面活性剤が要望 されるる。 Rẹd ${ }^{78)}$ らは粉乳を $6 \%$ 添加することを推めて 㕫。

マシュマロの場合も起ホウ的作用が必要であって通常 郎白や他の界面活性剤が利用される。

野菜, 果実の乾燥食品製造工程に水の蒸発効率を上げ る目的から, 界面活性剤の利用が最近開発されつつあ る ${ }^{79)}$ 。すなわち, リンゴやモモのような多孔質の果実を 乾燥する前に界面活性剂で処理すると, 乾燥の初期段階 (定常速度期間) における乾燥速度が速くなることが判 明した。しかし，野菜類や種なしブドウでは効果なく， またいずれの場合も乾燥の後期 (速度減衰期) では効果 がなかった。

米国農務省西部研究所の開発したフォームマットドラ イング法 ${ }^{80}$ は従来の乾燥法に比し, 乾燥能力の増大, 製 品も多孔性にさせることによって速溶性を改良するなど の利点より注目をあびている。本法はコーヒー，果実ピ ューレー, 果実野菜ジュースなどの乾燥においてホウマ ツ安定剤 (foam stabilizer) として，モノグリセリド， ショ糖エステル，ソルビタンエステルなどを，タンパク 質やメチルセルロースなどとともに用いると有効である
とし，乾燥前にあらかビめア゙ヷ立たせたものを得るためい に使用することを絶詨条件にしでいる ${ }^{81)}$ 。

\section{4 アワ立ち抑制剤としての利用}

先述の作用とはまったく逆に製造工程中のアワ立ち現 象を抑制する場合にも界面活性剤の応用例を見ることが できる。このような作用に界面活性剤を選択する場合， 乳化㨈として選択する場合よりさらにトライアンドェラ 一式に捜さねばならない゙，ア゙ウ立ち抑制作用はそれぞれ

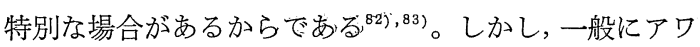
物質に不溶性の物質である心をが必要である。

食品関係に使周されるアり抑制剂は一般に親油性の脂 肪酸エステル類が多い゙为，最も効果的なものはシリコー ン製品であろら。

牛乳を真空濃縮してコンデンスミルグを製造する場合 に，アワ立ちが激しく作業上の能率を低下させるが，モ ノグリセリド，ソルビタンモノステアレートの添加は起

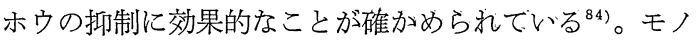
グリセリドではステアレートがアワを安定化するが，一 方オレート, リノレートはアワを不安定にするのでジュ. 一スの濃縮工程に $0.5 \%$ の不飽和蒸留モノグリセリドの 添加により，実験室的には好結果が得られており ${ }^{85)}$, 酵 母の製造, ペニシリンの発酵などにモノおよびジグリセ リドが消ホウ剤として用いられている ${ }^{86)}$ 。

このほか一見無縁にみえる日本古来の伝統的な食品で ある豆腐にまで及んでいる。豆腐は水に浸セキした大豆 を摩砕し蒸留したのち, 圧搾して分離した豆乳に硫酸か ルシウムなどの凝固剤を添加して作られること ${ }^{87)}$ 。ま党 歩留まりが向上し，製品のキメ，光沢がよくなり食感を 改良することなどである ${ }^{88)}$

界面活性剤としては，モノグリセリド(蒸留品)，モ ノ，ジグリセリド混合物，ショ糖ジェステル，ソルビタ ンエステルなどが単独または混合して用いられ, 添加量 は消ホウのみを目的とする場合は豆かゆに対し 0.005〜 $0.03 \%$ ，その他の効果を期待する場合は原料大豆に対し 0.1 2.5\%を水にホモゲナイズして豆乳に加えて用い るが，この場合，直接豆かゆに加えれば消ホウの効果も， あわせて利用できる。

これらの親油性界面活性剤を添加した豆腐は保水性が よく，しかも食感をそこならことがないので，収率も 10\% 程度は向上させることができるといわれている ${ }^{899}$ 。 現在豆腐にはモノグリセリドを主体として年間数百 $\mathrm{t}$ が 使用されているといわれている。

\section{5 湿潤剮, 分散刘としての利用}

チョコレートは油相中に砂糖およびココア固形物が微. 粉体の䀣濁している系であるが，レシチンは油溶性の湿: 潤剤として加熱したチョコレート塊中の固体微粒子間の; 
凝集を低減し，粘度を低下させる作用をもち，高価なコ コアバターを多量使わなくても砂糖を多量混合すること を可能にする ${ }^{90) 。 ~}$

これは界面活性剤が固体粒子の表面に吸着されてでき る層によって相互の引力的な表面力に影響しているもの と解される。レシチンはまた, チョコレート中の油脂の 結晶に対して分散的作用を有しチョコレートの表面に生 じるブルーミング現象を抑制する効果を有している，ブ ルーミング抑制荗としては，このほかグリセリンおよび イノシットの脂肪酸エステルとポリオキシエチレンの脂 肪エステル ${ }^{911}$ ，ソルビタンモノステアレートとポリオキ シエチレンソルビタンモノステアレート ${ }^{922}$ な゙があ る ${ }^{93)}$ 。

チューインガムはエステルガム，天然ガム，可塑片な どの親油性成分とポリ酢酸ビニル, 砂糖, ブドウ糖, 水 あめ, 色素, 香料などの親水性成分拉よびタルク，炭酸 カルシウムなどの充テン剤を加熱混合して製造されるの であるが，元来混ざりにくいものを均一に混合するため に界面活性剂の使用が有効である。界面活性剂使用の歴 史は浅くここ 10 数年のことであっで ${ }^{94)}$ ，単に作業性を 上げる目的のみならず，歯つきの防止また弾性をおさ え, ガムに柔軟性と可塑性を与え, チューイング性を改 良する効果がある。従来から主としてモノグリセリド， ソルビタンエステルがガムベースに対し 1 数 \% 使用 されている。最近はショ糖エステルが矛軟性, 可塑性の 向上および風味への好影響の点でかなり用いられるよう になっており，HLB 価 5〜7 の製品は中程度の柔軟性 を与え, HLB 9 11 の親水性のものはガムの柔軟性を 大幅に増加させる。

従来はガムの着色には油溶性の色素が用いられていた が，今日では油溶性の色素はほとんど禁止されており， ガムに水溶性の色素を用いるには, ソルビタンエステル を加熱溶解し，これに水溶性色素をそのままか，なたは 水溶液として加え, 均質化して固化したのち, 粉末とし たものをチューインガムに加えると，水溶性色素はバラ エティーがあるので，任意の着色が得られ，しかも色素 の溶出も少ないといわれている年。

インスタントココア，脱粉などに界面活性郕を利用し て, 粒子の分散性を高め沈降速度を押さえる利用は数多 くある ${ }^{96)}$ 。

粉乳の製造に当たって界面活性剤を利用し，品質を高 めることが行なわれている。従来粉乳を水に溶く場合に 経験するところであるが，まわりが湿って内部がほぐれ ず水に浮く塊になってしまう。数 $\mathrm{min}$, 激しくかくはん するとやっとのことで塊がくだけて，粉乳が溶け始め る。このような粉乳の性質を改善し, すぐに湿りすぐに 沈殿する粉乳を製造するのに界面活性剤が湿潤分散剤と して效用される。このような粉乳の易溶化と変わり牛乳
を粉末化する前に界面活性剤を牛乳に添加する方法があ る ${ }^{97)}$ 。オランダの Sjollema ${ }^{98)}$ の考案した方法は, 粉乳 あるいは粉状ミルク製品に $0.2 \sim 4 \%$ ．の無水界面活性剂 を混合する方法である。かれの説明によると，界面活性 剂を添加すると, 各粉の粒子のまわりに連続する層が形 成され，この層が一方で各粉末粒子の湿りを促し，他方 では粒子中に水の浸透するのを遅らせる。こうした二つ の作用によって粒子は水と作用乙膨潤し固をる場合より も，はるかに早く湿りを帯びるのである。それゆえに粒 子はただちに沈殿してすぐ分解し始める。界面活性剂は 各粉乳粒子の面に点として存在すればよいのだからここ うした即溶作用を得るための界面活性剂量はごく微量で 充分であるとされる。また使用する界面活性剤として は,

1）普通の温度で液体のこと, たとえばオレイン酸

2) 液体油を半分ないし8 倍の量加えると液状になる もの，たとえばグリセリルモノラウレート

3）粉乳と界面活性剂とを処理前に界面活性剂の融点 以上に加熱し，処理後再び冷却すること，これはた とえば大豆レシチンの場合

4) 界面活性剤を揮発性溶剂に溶かし，粉乳と混じ溶 剂を再び揮発させること，以上ここにあげたどの界 面活性剤に適用してもさしつかえない などの条件をあげている。

またエバミルクの殺菌時の熱凝集防止にはショ糖エス テルなどの親水性活性剤が有効といわれている ${ }^{99}$ 。

製糖工場においては，すそ物前糖（最終工程での砂糖 の回収のため結晶カン操作) にメチルグルコシドジ脂肪 酸エステルを微量添加すると, 糖液砂糖混合物の粘度を 下げる煎糖時間, 結晶の分離時間定短縮することができ るといら報告もある(100)。

近年，米国に扔いて固形の柑樀オイルフレーバーが開 発され, 本品はフレーバーが安定であり取扱の簡易なこ とから消費が増大し注目されているが，乾燥柑樀ジュ一 不製品では固形の天然フレーバーが必要とされ，そのた めにゼラチン, ソルビット，植物ガムなどで揮発性オイ ルフレーバーの固定剤として可食性の炭水化物がよいと 考えられるが，その必要条件は冷水への溶解性がよく， 無臭で長期貯蔵中にも結晶化しないことなどがあげられ る。Griffin ${ }^{101)}$ はソルビットでフルーツフレーバーを固

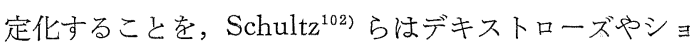
糖を用いてオレンジオイルフレーバーを固化した。

Swisher ${ }^{103)}$ はコーンシロップ固形物, 抗酸化剂, 乳 化剂を用いた。その後, Schultz ${ }^{104)}$, Talburt ${ }^{105)}$ らの粒 状化などの実用化研究がカリホルニヤの米国農務省西部 研究所で進められ, 非常に安定な製品として商業採算に 乗るまでとなり，“Perma-Stabil” の商品名で市販され るに至った。 
Swisher ${ }^{106)}$ の行なえるパイロットプラントにおける 例を示せば，スチームジャケット加熱のステンレス製の かまにグリセリン $480 \mathrm{~g}$ を入れ, $120^{\circ} \mathrm{C}$ に加熱したもの に 4,716 g の固形シロップを徐々に加え混合し, これを $110^{\circ} \mathrm{C}$ に冷却し, ナトリウムスルホアセテートのモノグ リセリド $84 \mathrm{~g}$ を分散剂として使用し，一方冷圧搾オレ ンジオイルに $0.05 \%$ の BHA 抗酸化剤を加えたもの $720 \mathrm{~g}$ を作っておき, これを先の $108^{\circ} \mathrm{C}$ にした混合物に 静かに添加する, この半ゲル状の乳化物を二重加熱管に 送り底部の細孔から $36 \mathrm{lb} / \mathrm{in}^{2}$ の圧力で抽出し, 繊維状 としさらに室温または $-24^{\circ} \mathrm{C}$ のイソプロパノール中に 出す。繊維状固形フレーバーを破研後アルコールで洗浄 加熱真空乾燥する。この固形フレーバーは安定であって 製造の際界面活性剂を使用することは揮発性オイルの含 有量を増大させるだけでなく，オイル粒子の径を小さく 一定にする分散効果を示す。この分散剤としてはレシチ ン，ナトリウムスルホアセテートのモノおよびジグリセ リドが適当で揮発性オイルの 10 15\% の添加量がよい とされている。

また Schultz らは加熱溶解させた糖類に精油を添加 し, 固化後粉末化する粉末香料の製造法において製造中 および製品保存中の香料の保留にはショ糖ジパルミテー ト ${ }^{107)}$ ，レシチン ${ }^{108)}$ の 0.1〜 5\% 添加が有効であること， また乳化香料を経て糖類中に精油を含有させる粉末香料 の場合には, ショ糖モノパルミテート ${ }^{109}$ 夯有効である と報告している。

家畜飼料に最近油脂を添加して栄養的価值を高めるこ と, また食欲を増進させ消化機能の活発化と吸収を計る ため飼料フレーバーの添加が害用化され始めているが, この目的のために油脂の表面張力を低減し, 飼料中に油 脂および香料の分散を容易にし, 飼料に湿り気を与える ために界面活性剤が油に対し $0.1 \%$ 程度添加される。

果実や野菜を油脂やワックスのエマルションにした膜 でコーチングすることも実際に行なわれており，多くの 特許がある ${ }^{110)}$ 。この目的は 果実類の青枯れ病や 水分の 損失を減少するために実施されるもので, カリホルニヤ やフロリダのオレンジの $75 \%$ 以上がワックスエマルシ ョンで実施されている ${ }^{111}$ 。

水蒸気やガスの発散をこのワックスの膜が拉さえてい るのであるが, ワックス膜への水蒸気の溶解度は膜の厚 さに支配されるが，これはエマルションの濃度次第であ り平均 1 2 2 といわれている。連続した膜を形成する ことも重要な因子であるので湿潤性と伸展性むこのエマ ルションには必要で, 普通 3 4\% パラフィンロウと $0.6 \%$ 程度の鉱物油，あるいは $28 \%$ パラフィンと 8.5 \%ベントナイトがカーナバロウと一緒に添加され, 約 18 〜35\% の全国体を含有するエマルションで表面張力は 32 37 dyne $/ \mathrm{cm}$ 程度である。
まず洗浄した果実, 野菜を乾燥せず室温でワックスエ マルションにつけ約 $2 \mathrm{~min}$ 滴を切る, その後乾燥空気 中で乾かすか，あるいは約 $10 \mathrm{~min}$ ファン送風して仕上 げるのである。Trout ${ }^{112)}$ はワックスエマルションの場 合は分散粒子が $1 \mu$ 以下でないと透明にならないから， むしろ液状油エマルションがよいとしている。またこの ようなコーチングエマルションによる保存性の向上例と して, 卵の保存性を高める目的でエマルション組成物の 特許が出願されている ${ }^{113)}$ 。Romanoff ${ }^{114)} ら$ 鉣物油に ステアリン酸と乳酸を配合したエマルションで卵の外殼 から処理して，卵の殼から浸透する水蒸気を約 $1 \%$ 押さ えることができると述べている。

エアロゾル食品の場合, エアロゾルや噴霧は普通スプ レーやフレオンのような媒体液の気化による機械的作用 によって作ることができる。この際界面活性剤をこれら の原料添加することがあるが，乳化を目的として使う のではなく, エアロゾルの湿潤性やその他の特性を改良 するためである。

\section{6 結晶促進剤, 結晶防止剂としての利用}

油脂類のように過冷却を起こす系にあっては結晶核の 界面に界面活性剂吕吸着して結晶の防止作用を表わす。 綿実油などから作るサラダ油にレシチンが結晶防止剂と して使用される。このほか酸化重合油, ソルビットある 、は多価アルコール類の脂肪酸エステルも結晶防止剤と して効果を示す ${ }^{115)}$ 。油脂から 固体脂および液体油の分 別に際し溶融状態時に界面活性剂を添加し，口別収量を あげかつ口過分離時間を減少する方法がサラダ油あるい は乾性油の製造に考案されているが，この界面活性㓮と してデキストリンの脂肪酸 エステル ${ }^{116)}$ ， ショ糖脂肪酸 エステル117)，グルコース，あるいはグルコノデルタラ クトンおよびグルコニック酸などグルコール誘導体のエ ステル118)などがあげられる。

モノグリセリドの結晶を $。$ 型に保つために，プロピレ ングリコール脂肪酸エステルを添加し，これを結合結晶 (conjoined crystal) と呼び起ホウ性能を改良したこと は前に述べた。

練りようかんは，あんと砂糖と寒天を主原料とし、こ れにときには水あめ, デキストリンなどを加え煮つめな がら練り上げ，型に流して固化させるものである。水あ めを使用しない上物の練りようかんは流通の段階で表面 に砂糖のシャリ（結晶）がでたり，また内部に大粒の砂 糖の晶出がでたりする。ショ糖エステルには過飽和の濃 厚糖液からの砂糖結晶を変形させる作用があり, ショ糖 の結晶中にさく状に配列して結晶強度を弱めたり, 結晶 を微細化する作用があるため ${ }^{119}$ ，ようかんやあんのシャ リ防止に有効であって，広く使用されるようになってお り,またようかんのチョウ度を増し, 寒天の節約にな 
り, 粘性を減少させ, 歯ざわりの改良, カッティング がスムースになるなどの効果を有する。対砂糖 $0.2 \sim$ $0.6 \%$ のジェステルまたはモノジェステルを仕込み時に 砂糖にふるい込んで用いる。

そのほか,グルタミン酸, ヌクレオチドなどの複合調 味料粉末のコーチング剤として, ショ糖パルミテートが 防湿の目的で使用され $れ^{120)}$, また双晶, 混晶の防止には, ソルビタンエステル，ショ糖エステル，モノグリセリド などの $0.01 \sim 0.1 \%$ 使用が有効であるといわれる ${ }^{121)}$ 。

\section{7 界面活性剂とデンプンの複合体利用}

アミロースはある種の界面活性剤と複合体を作って不 溶性となり, ヨード反応を示さず ${ }^{122}$ 熱湯に入れてもゲ ル化を起こさなくなる。普通，コ化デンプン粒は枝分か れ分子が広がるかまたは網状構造をしており，その中に まっすぐ伸びた直鎖分子が混ざっていて互に水素結合 か，ミセル構造を保っていると考えられている。しかし デンプン粒が適当な高分子脂肪化合物の存在下でコ化さ れると直鎖分子の遊離されたところでただちに脂肪酸基 とラセン構造をつくり, 直鎖分子の広がりを少なくして 網状構造を固くしてしまう。

Schoch, $\mathrm{Gray}^{123)}$ らによると, コ化したデンプンはあ らい網状構造をもつが，これに界面活性剂などの長いア ルキル基が加わると自由な直鎖部分はアルキル基の周囲 をラセン状にとりまいた複合体（包接化合物）を形成す る(図-3)。この現象はヨウ素, 高級アルコール類とデ ンプンとの複合体形成と同様であり，アミロースと界面 活性剤の複合体のラセンの 1 巻きは，6 個のグルコース 分子からなっていることが証明されている。
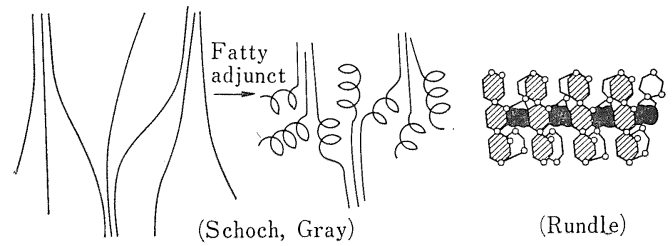

図-3 アミロースの脂肪酸付加物および デンプンのラセン構造

界面活性剤によるデンプンの老化防止作用などがこの ような複合体形成と密接な関係を有していることは明ら かであり，少なくともパンについて有効な老化防止剤は すべてこの種の複合体 ${ }^{124)}$ を作る。しかしいままでのと ころでは, 複合体形成力の大小が, 老化防止能の大小で あるというほどの積極的な証明はなされていない。

とくにパンなどの焼成品が経日的に変化するいわゆる 老化現象によって，かたく食味の劣化を呈するが，焼き あげたパンをやわらかく，かつ長時間その状態を保たせ るために界面活性剂が老化防止剤 (柔軟剂) として実用
されている。パンの軟化作用として各種の界面活性剂効 果を示した例も多く ${ }^{125)}$ ，またなぜこのよらな作用を呈す るかについての機構上の論説も多く述べられている ${ }^{126) 。}$ 生地および焼成中，あるい製品に存するグルテンおよ びデンプンの水分移動に対し界面活性剂が効果的に調整 する作用によって見かけの老化を防止しているとの説が 多く取りあげられている。

改めて述べるまでもないことであろらが，デンプンの 老化現象は $\mathrm{Katz}^{127)}$ の業績以降次のように考えられて いる。生デンプンは明りょうなX線回折像を与える結晶 構造をもつが水を加えて加熱し，コ化させると結晶構造 が失われる(デンプンの $\alpha$ 化)。これを放置すると再び 結晶構造を呈するようになり，同時に酸素作用も受けに くくなってくる。この老化機構は，いったん水和されて ほぐされたデンプン分子のグルコース鎖が，水素結合に よる橋カケ反応によって再び三次元的な構造を形成する ことによると考光られている。またデンプンを構成する アミロースとアミロペクチンについては，アミロースの 老化がコ化後ただちに始まるのに比較して, アミロペク チンの老化は徐々に行なわれる。

このようにデンプンと複合体を作る現象はマッシュポ テトの製造工程に利用され品質の向上に役立っている。 すなわち，モノグリセリド（モノパルミテート）の添加 により。粉末マッシュポテトを還元する場合，ノリ状に

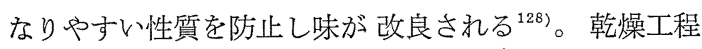
にあってもモノグリセリド $0.7 \%$ 以上を添加するときき は乾燥ドラムからマッシュを早く離れさす作用もあっト きわめて効果的なようである。

このほかマカロニ製造，とくにカン詰のスパゲッテ ィ，マカロニなどがレストランで再度熱処理を受ける 際アアミロースゲル形成を抑制するため穀粉に対して 1 〜2\% の純モノグリセリドを添加しておくと適度のかた さの保持のできた食味感覚のものができる ${ }^{1299}$ 。

さらにめん類に対する効果は生地がしまり, 弾力が増 強される(カン水の量を隇らすことができる)。生地が べとつかなくなり，作業性が向上する。生地吸水率の向 上，煮くづれ防止，ゆで水の濁り減少，歩どまり向上， 製品の白度向上などが発表されている。ショ糖エステ ル ${ }^{130)}$, ショ糖エステルとポリリン酸塩の併用 ${ }^{131}$ で $0.5 \%$ 程度を小麦粉と混合，または添加水に溶いて用いたり， 油脂をめん中に均一に練り込むために，油脂にレシチ ン，モノグリセリドソルビタンエステルなどを合計量 で対油脂 $0.7 \sim 4.5 \%$ 用い，水を加えて乳化し，小麦粉 と練り合わせる方法むある ${ }^{132)}$ 。また味付け即席中華め んの製法において, めんのしまりを良くし，調理後のめ んに味を残さぬために，二化前に味付けをすることが好 ましく，そのためにはモノグリセリドを対粉 $0.15 \%$ 程 度添加することが有効であって, 同時に蒸募中のめんの 
相互付着も防止できるといら ${ }^{133)}$ 。また 同じ目的で調味 液中にモノグリセリドを $0.5 \%$ 混入しておいたものに生 のめん線を浸せきする方法もある ${ }^{134)}$ 。

最近は, 蒸留モノグリセリドを水分散性にしたもの ${ }^{135)}$ 蒸留モノグリセリドとショ糖モノエステルを水中分散さ せたクリーム状のめん用改良刻む発売されている。いず れにしても界面活性剤が水によく溶解, 分散し, 小麦粉 とよく混合させることが必要であり, 各種の効果の主因 はいずれもデンプンー界面活性剤複合体（starch-surfactant complex) 形成にあると考えられる。

そのほか，イモデンプンの水洗, 沈殿精製に界面活性 剂を利用して ${ }^{136)}$, 不純物であるタンパク質含量の少ない デンプン製造工程にアルキルベンゼンスルホン酸ナトリ ウムなどの界面活性剤が利用されている ${ }^{137) 。 ~}$

カスタードクリーム類, その他の加糖したフラワーペ 一スト類が製菓製パン材料として出回っているが，これ らはデンプンの老化によって保水力を失い, 離水しやす くなる。天然ガム質, 合成コ料なども離水防止の目的で 用いられるが,ショ糖エステルのような界面活性剤にも 防止効果が報告されている。前沢らはトウモロコシデン プンのコ化前に各種の界面活性剤などを添加して, 離水 を経日的に測定し HLB 価の低いショ糖エステルが有効 であることを報告している年8 。

デンプンゼリーやペーストに対する界面活性剤の作用 については, 各種のモノェステル類は一般にゲル化の温 度を上げる作用があり，レシチン，ジエステル類はゲル 化温度を下げるかあるいは変えない。デンプンの種類, 界面活性㓮の種類により, コ化後のゲル強度を大きくし たりまた逆に小さくしたりする作用があって効果は複雑 であり，一概に語れず，使用するに当たっては予備的な 試験が必要である。とくにモノエステル含量の多い界面 活性剤の場合は使用法によってはゲル化温度が上昇し。 ゲル化しきれない場合もあるので注意を要するが, 油脂 を併用するとゲル化温度を下げることができる。またゲ ル強度が老化によって上るのを防ぐ作用では, ショ糖モ ノエステルがすぐれている ${ }^{139)}$

あられ，おかき，せんべいのような米菓は，もち米。 らるち米またはその粉末を主原料としてもちを作り, 整 型後乾燥してから焼き上げ, 調味液を上がけする。問題 点として乾燥工程に沶いて生地が均一に榦燥しにくく, 破損の原因となり，また製品の型上がり，ウキが不揃い なものができやすいなどの欠点を有する。これらの改良 にはソルビットも有効であるが隹，モノグリセリド， PG エステル, ソルビタンエステル, ショ糖エステルな どの界面活性剤を単独をたはソルビットと併用して用い ると, 水分の表面への伝導性がよくなり, 割れも防止で きるといわれている。また製品のウキ，巣立ちもよくな り,ショートネスがでる。
もち類，特にもち菒子類は製品の硬化が早く，これを 少しでも遅らせることは重要なことで, ソルビット，砂 糖の添加も有効であるが，これはショ糖エステルの添加 が有効であり，硬化抑制力むかなり大きくなるようであ $る^{141)}$ 。

\section{8 可塑悭体としての利用}

モノグリセリドなどの活性剤のあるものは, 界面活性 だけでなく, 結晶の移行性向と油脂への不溶性からこれ らの特長を生かして，その可塑性を利用される。

マーガリンのレオロジ一的性質を付与させるために配 合油を調整する場合, 全水添型の硬化油かもしくは液体 油と硬化油または固形脂との混合型が考えられるが，二 レステリン水準低下を目的としたマーガリンの場合はで きるだけ 飽和脂肪酸含量を減少し，しかむ plastic far を形成する必要上モノグリセリド，ソルビタンモノステ アレートの適用を考え，これらの効果を三飽和グリセリ ドのそれと比較しつつ，マーガリンを試作し検討したが 図-4，5 にみるようにモノグリセリド，ソルビタンモノ ステアレートの混合型の方がコレステリン低下作用が女 ることが明らか䛉認められる ${ }^{137 ?}$ 。

米国農務省の北部研究所の Cowan, Senti $ら^{142}$ は綿 実サラダ油にモノグリセリドを添加し，可塑性温度に対 する領域を広め，しかもテンパリングによってモノグリ セリド結晶が球形に液状油をくるむ性向を見いだし，低 温にてやわらかく，高温 $\left(433 \sim 45^{\circ} \mathrm{C}\right)$ にても原形を保つ

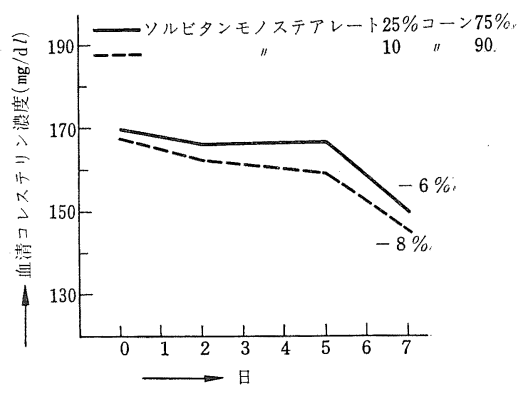

図-4

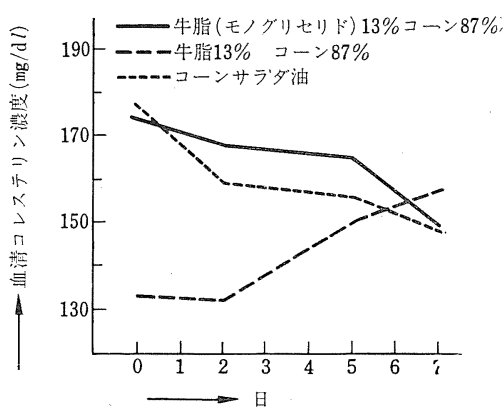

図-5 
特性のあるマーガリンようのグローバル スプレッド (global spread) を開発し，軍用スプレッドとして用い られている。

global spread の組成

\begin{tabular}{l|l}
\hline 綿実サラダ油 & $84 \%$ \\
蒸留モノグリセリド & 16 \\
食 塩 & 3.0 \\
着色剂 & 0.2 \\
賦香剤 & 0.2 \\
プロピルガレート & 0.01 \\
クェン酸 & 0.005 \\
ビタミン A, D & tr. \\
\hline
\end{tabular}

Kapsalis ら ${ }^{143}$ は天然バターの伸展性，かたさの影響 としてモレノグリセリド, ツイーン (Tween), スパン (Span), レシチン, バターミルクソリッド, 脱脂乳など をあげ，バターの伸展性は 10〜 40\% 増加，かたさは 3 〜21\% 低下すると報告している。

また湿潤剂, 分散剂としての利用の項で述べたチュー インガムに添加する界面活性剤も可塑性体としての利用 の例である。

（昭和 44 年 3 月 7 日）

\section{文献}

1) B.R. Harris, U.S., 1,917,254 (1933), Brit., 378,373

2) C.R. Schoenfield, Brit., 657,630 (1951)

3) B.R. Harris, U.S., 1,917,249 60 (1933)

4) Sambuc, E. Naudet, Rev. Franc Corps Gas, 11 (3), 127 132 (1964)

5) 寺田, 日本特許, 281,174

6) 寺田, 日本特許, 270,404

7) L.C. Brown, U.S., 1,926,369 (1933)

8) H.S. Coith, A.S. Richardson, V.M. Votaw, U.S., 2,132,396 97 (1938); B.R. Harris, U.S., 2,024, 357 (1935); U.S., 2,132,416 7 (1938); U.S., 2,158,775 (1939); P.L. Julian et al., U.S., 2,690,971 (1954); U.S., 3, 004,853 (1958)

9) E. Handschmaker et ai., U.S., 3,069,270 (1962); S.B. Radlove, U.S., 3,029, 147 (1962); U.S., 2,996,397 (1961); J.B. Thompson, U.S., 2,744,825 (1956); S. S. Chang, U.S., 2,966,410 (1960); W.F. Schroeder, U.S., 2,968,564 (1961)

10) H. Mack, I.A. MacDonald, J. Am. Oil Chemisis' Soc., 37, 651 (1960)

11) N.H. Kuhrt, E.A. Welch, J. Am. Oil Chemisis' Soc., 27, 344 (1950)

12) C.D. Jooste, A.D. Mackey, Food Res, 17, 185 (1952)

13) C.D. Pratt, W.W. Hays, Food Eng, May 109 (1952)

14) H.H. Young, H.H. Spitzmeller, U.S., 2,963,371 (1960)

15) Jordan, U.S., 1,859,240 (1932)

16) P. Backer, "Emulsion Theory and Practice" (1957), Reinhold Publishing Corporation, New York

17）中土，シュガーエステル 商工財務研究会，アルプスシリ 一ズ，第 174 (1961)

18）安達ら, 特許公告, 昭 43-6,967
19) Brooks "Critical Studies in the Legal Chemistry of Foods" p. 145 (1927), New York

20) Robinson, Am. Food J., 19, 187 (1924)

21) Cobb, Hunt, J. Am. Leather Chem. Assoc, 21, 18 (1926)

22) Epstein. U.S., 1,595,765 (1926)

23) J.W. Corran, "Emulsion Technology" p. 176 192 (1946), Brooklyn Chemical Publishing Co.

24）永沢 “食品コロイド学” (1967)

25) E.L. Saul, Am. Perfumer, 56, 311 (1950)

26) Whitmore, Linehan, Ind. Eng. Chem., 21, 878 (1929)

27) 藤田, New Food Ind., 6 (5), 70 76 (1964)

28）秋山ら, 特許公告, 昭 38-3,948

29）美間ら，特許公告，昭 38-2,5262

30) T.H. Sohultz et al., U.S., 2,929,722 ((1960)

31) T.H. Sohultz et al., U.S., 2,929,723 (1960)

32) T.H. Sohultz et al., Food Tech, 17 (9), 100 102 (1963)

33) 野村, Nerw Food Ind., 4 (6), 47-52 (1962)

34) R. Faivre, Chimie \& Industri, 56, 337 (1946)

35) L. Nobile, U.S., 3,164,477 (1965)

36) 中野, 特許公告, 昭 41-16,103

37）上野, 特許公告, 昭 40-8,788

38）青山，特許公告，昭 40-6,391

39）長西，特許公告，昭 39-6,790

40）鉣治，特許公告，昭 $42-22,185$

41）北山，特許公告, 昭 41-16,548

42）伊藤ら，乙ょう油之技術，304 号，昭 $35 ， 11$ 月

43）伊藤ら, 特許公告, 昭 37-9,294

44）梅田, 特許公告, 昭 $37-1,6663$

45） 宮川, New Food Ind., 9 (9), 1 7 (1967)

46) Ledoga, SpA, Tech. Bulletin Sugar Ester (1959)

47) 成沢, 特許公告, 昭 39-25,638

48）成沢，特許公告，昭 39-25,641

49) General Mills Co., 特許公告, 昭 41-20,055, 20,057, 20,058 , 昭 42-15721

50）小菅，特許公告，昭 39-14,475

51）石井ら, 特許公告, 昭 $37-13,702$

52）松下, 特許公告, 昭 $42-3,060$

53）亀崎, 特許公告, 昭 $42-5,181$

54）丹羽, 特許公告, 昭 $31-2,874$; 太田, 特許公告, 昭 363,627 ; 山中, 特許公告, 昭 36-10,681; 杉, 特許公告; 昭 41-3,071

55) J.L. Schiedman, U.S., 2,522,050 (1950); C.E. Evans, U.S., 3, 014, 801 (1961)

56) B.R. Harris, U.S., 2,902,372 (1959)

57) V.E. Maturi, U.S., 2,933,397 (1959)

58) N.F. Johnston, H.H. Favor, Food Eng., Sep. 76, (1947)

59) B.E. Harper, Food Manuf., 28, Nov. (1953)

60) S. Cressey, Food Manuf., 32, p. 165 (1957)

61) M.A. Cookson, J.B.M. Coppoch, J. Sci. Food Ag. ric, 5, 8 (1954)

62) N.H. Kuhrt, A. Russell, U.S., 3,034, 897, 3, 034,898, 3034902 (1962); H.M. Fett, J. Am. Oil Chemists." Soc., 40, 81 (1963)

63) 瀬谷, New Food Ind., 5 (10), 32 33 (1963)

64）瀬谷, 食品工業, 8 (17), 109 111 (1965)

65）古寺, 食品工業, 9 (8), 62 66 (1966)

66) 西山, New Food Ind., 9 (10), 26 29 (1967)

67）福永ら, 特許公告, 昭 40-24,504

68) E.A. Farrand, Chem. \& Ind. April 27 (1957) 
69) D.P. Kidger et al., U.S., 3,042,530 (1962)

70) Glenn Schulman, U.S., 2, 864,705; 2,864,703 (1958)

71) Sol, B. Radlone, U.S., 3,029,147 (1962)

72) H.M. Fett, J. Am. Oil Chemists'Soc., 40, 81 (1963)

73）寺田, 特許公告, 523,329

74) A.S. Geisler, J. Am. Oil Chemists' Soc., 38, 306 309 (1961)

75) P.H. Jracy, International Association of Ice Cream Manufactures, The 44th Anual Convention, Atlantic City N.J, p. 8 (1948)

76) W.S. Arbuckle, Ice Cream Trade Journal, \$6, 106 (1950)

77) P.G. Keeney, P.V. Josephson, Ice Cream Trade Journal, 54, 32 (1958)

78) W.H.E. Reid, W.C. Ecklee, Missouri Agr. Expt Sta Res. Bull. 214 (1934)

79) G.D. Saravacus, S.E. Charm, Food Tech. 16, 91 93 (1962)

80) A.I.Jr. Morgan, L.F. Ginnette, J.M. Randall, R.P. Graham, Food Eng., 34, Aug. (1962); M.B. Hart, A.L. Morgan, Food Tech., 17, 90 92 (1963)

81) F.K. Lawler, Food Eng., 34 (Feb.) 34 (1962); A.L Morgan et al, Food Tech., 15, 37-39 (1961); W.C. Rockwell, E. Lowe, A.L. Morgan, L.F. Ginnette, R.P. Graham, Food Eng., 34 Aug. (1962) ; M.B Hart, A.L. Morgan, Food Tech., 17, 90 92 (1963)

82) P. Dervichian, F. Lachampt, Bull. Soc. Chem., 486 91 (1946)

83) L. Schedlousky, N.Y. Ann, Acad Sci., 46, 427 50 (1946)

84) J.B. Brunner, J. Dairy Sci. 33, 741 (1950); R.G. Jensen, M.E. Morgan, J. Dairy Sci., 42, 332 (1959); R.G. Jensen, G.E. Gander, A.H. Duthie, J. Dairy Sci., 42, 913 (1959)

85) G.H. Doerfert, Food Eng., 34, Nov. 97 (1962)

86) R. Schnliden, Seifen-Öle-Fette-Wachse, 88 (6), 137 (1962)

87）佐藤ら, 特許公告, 昭 43-8,685

88） 今井ら, 特許公告, 昭 43-8,684

89）宮川, 食品工業, 9 (8), 44 51 (1966)

90) E.O. Working, U.S., 1,781,672 (1930); J. Stanley, "Confectionery Production" p. 2490 (1939)

91) S.T. Cross, U.S., 2,626,216 (1953)

92) S.T. Cross, C.G. Griffin et al., Food Tech., 6, 21 (1952)

93）渡辺, 食品工業, 9 (20)，120 122（1966）; 中西, “千 ヨコレート・ココア製造の理論と実際” (1965) 光琳書院; 渡辺, New Food Ind., 7 (8), 81 84 (1965)

94) 手塚, “チューインガム工業” (1964) 只野研究所発行

95）星野, 任意の色調を有するチューインガム 製港, 特許公 告, 昭 $35-16,987$

96) 中西ら, New Food Ind., 4 (5), 70 81 (1962); 中西 ら, 特許公告, 昭 39-10,235; 高野ら, 特許公告, 昭 36 $\sim 10,690$

97) D.P. 84,508, Brit., 701,697, U.S. 2,399,565

98) A. Sjollema, 特許公告, 昭 35-12178.

99）藤田, 食品工業, 15, 48 (1968)

100) J. Kuse, Int. Sug. I., 68, 267 270 (1966)

101) W.C. Griffin, U.S., 2,566,410 (1951)

102) T.H. Schultz, K.P. Dimick, B. Makower, Food Tech., 10, 1 (1956)

103) H.E. Swisher, U.S., 2, 809, 895 (1957)

104) T.H. Schultz, H. Brown, L.H. Walker, U.S., $2,857,281(1958)$

105) T.H. Schultz, W.F. Talburt, Food Tech., 15 (4), 188 190 (1961)
106) H.E. Swisher, Food Tech., 17, 103 105 (1963)

107) T.H. Sohultz et al., U.S., 2,929,722 (1960)

108) T.H. Schultz et al., U.S., 2,929,723 (1960)

109) T.H. Schultz et al., Food Tech., 17 (9), 100 102 (1963)

110) Brogden, Trowbridge, U.S., 1,809,016(1931); Harrey, U.S., 1,909,860 (1933); Bridgeman, Schade, U.S., 1,943, 468 (1934); Mac Rill, U.S., 2, 019,758 (1935); Griffith, U.S., 2,288,351 (1942); Towner, Austral, 116,036 (1942); Harrdy, U.S., 2,364,632 (1944); Arabian, U.S., 2,560,148 (1951)

111) N.Y. Platenius (Cornell), Agr. Expt. Sta. Bull, 723, 43, (1939)

112) Trout, J. Council Sci. Ind. Res., 15, 26 (1942)

113) Flowler, Benfield, Brit., 419,668 (1933); Chuck, U.S., 2,038, 540 (1936); Schmidt, Brit., 496, 659 (1938); U.S., 2, 222,000 (1940)

114) A.L. Romanoff, W.P. Yushok, Food Res., 13, 331 (1948)

115) D.P. Grettie, U.S., 2,050,528 (1936); W. Clayton, S. Back, R.I. Johnson, J.F. Morse, U.S., 2, 097,720 (1937); E.W. Eckey, E.S. Lutton, U.S., 2,266,591 (1944); H.D. Royce, U.S., 2, 418,668 (1947)

116) F.J. Baur, U.S., 3,059,008 (1962); Brit., 904,048 (1962)

117) D.F. Schmid, F.J. Baur, U.S., 3,059,009 (1962); U.S., 3, 059, 010 (1962)

118) F.J. Bour, U.S., 3, 059, 011 (1962)

119）精糖技術研究会誌，14，95～101（1964）

120) 石井ら, 特許公告, 昭 $37-13,725$

121）田中ら, 特許公告, 昭 40-3,465

122) E.M. Osman, S.R. Dix, Cereal Chem., 38, 464 (1960); E.M. Osman, S.J. Fles, Cereal Chem., 38, 449 (1961); R. Collison, Chem. \& Ind. 34, 1346 (1961)

123) V.M. Gray, T.J. Schoch, Die Starke, 14, 239 246 (1962)

124) C.W. Ofelt et al., Cereal Chem., 35, 142 145 (1958)

125) E.C. Edelwan et al., Cereal Chem., 27, 1 (1950);

C.W. Ofelt et al., Cereal Chem., 35, 137 (1958);

C.W. Ofelt et al., Cereal Chem., 35, 142 (1958)

126) P.H. Tracy, International Association of Ice Cream Manufacture, The 44th Anual Convertion Atlantic City N.J. (1948)

127) J.R. Katz, Z. Physik. Chem. (Leipzig), 150 A, 37 59 (1930)

128) J.Jr. Cording, U.S. Dept of Agr. Res Service GAE 18 (1959)

129) G.H. Doenfert, Food Eng., 34, Nov. (1962)

130）森ら, 特許公告, 昭 38-6,553

131）梅田ら, 特許公告, 昭 39-17,306

132) 中同ら, 特許公告, 昭 $35-15,418$

133）村岡，特許公告，昭 39-14,476

134）村岡, 特許公告, 昭 39-14,477

135）原田，食品と科学，10（5)，54～55（1968）

136）二国, 高岡, 不破, 農化, 26, 218 (1952)

137）寺田, 化学と工業, 16, 577 (1963)

138） 前沢，大久保，澱粉工業会誌，10，111 (1963)

139）佐藤，食糧气の科学と技術，10 号，79 食研 (1967)

140）斎藤, 特許公告, 昭 39-10,228

141）森, 入来, 特許公告, 昭 37-16,654

142) C. Cowan et al., J. Am. Oil Chemisis' Soc., 9 (1955); F.R. Senti et al., J. Am. Oil Chemisis' Soc., 110(1955); N.N. Hellman, H.F. Zobel, F.R. Senti, f. Am, Oil Chemisis' Soc., 489 (1955)

143) Kapsalis et al., J. Dairy Sci., 46, 107 (1963) 